\title{
PHRASAL VERBS IN AGATHA CHRISTIE “THE ABC MURDERS": A SYNTACTIC ANALYSIS
}

\author{
Sattar Obaid Habeeb, Asst.Prof.Nadya Khairy Muhammad Said \\ College of Education Ibn-Rushd for Human Sciences/ University of Baghdad
}

DOI: $10.37648 /$ ijrssh.v10i03.021

Received: $05^{\text {th }}$ June, 2020; Accepted: $28^{\text {th }}$ June, 2020; Published: $20^{\text {th }}$ July,2020

\begin{abstract}
Phrasal verb is one of the most important topics of English language because of the difficulty to understanding their forms and functions .

The concept of 'Phrasal Verbs' refers to a group of verbs which consist of two or moreparts , the first part is a lexical verb and the other one is called a particle (adverb or preposition). It is necessary to say that phrasal verbs are problematic, the problems of meaning and grammar are represented in how to understand their use correctly. Thus most people who are interested in the studying of English use single-word verbs would avoid to use phrasal verbs in their speech and writing.

The present study particularly attempts to shed light on the syntactic characteristics of English phrasal verbs in Agatha Christie's novel which is entitled 'The ABC Murders'(1936). In this study, phrasal verbs are classified into main types and subtypes according to their syntactic features. It also endeavors to focus on their forms.

The study aims to survey and analyze the syntactic types of phrasal verbs that are employed in Agatha Christie's 'The ABC Murders'(1936).It also aims to examine the similarities and differences between the forms/types of phrasal verbs in this novel to consider their high / low frequencies.

To achieve the aims of the present study, the adopted model of the analysis is basically Quirk et al(1985) which is believed to be related to the complexity of phrasal verbs and to the nature of the present study.

With regard to the data analysis, the conclusions of this study obviously show that phrasal verbs are rarely used in the Christie's novel under the analysis. Furthermore ,the conclusions have syntactically proved that 'Transitive' is the outstanding type of PVs comparing them to 'Intransitive'. 'Inseparable Transitive' is also the most dominant in this novel under analysis.
\end{abstract}

Keywords: Agatha Christie , Phrasal verbs, Transitivity, Separability . 


\section{INTRODUCTION}

Multi-word verbs are a group of verbs which consists of combinations such as : go on, go into, and get away with. Since the combinations lexically or syntactically function as a single word,they referred to as multi-word verbs which can be studied under the headings : Phrasal verbs, Prepositional verbs, and Phrasal- prepositional verbs(Quirk et al ,1985:1150).

Phrasal verb as a type of multi-word verbs ,this study intends to shed light on its importance and how to be understood, which still problematic for more speakers of English.

Phrasal verbs are usually considered the source of worrying as mentioned by Fletcher (2005:1), he emphasizes that these verbs are problematic not only for the learners of English but also for the people who are specialized in English language.

Simply, it can be said that the problems of meaning and grammar of phrasal verbs are represented in how to understand and use them in writing literary works ..

The present study identifies the phrasal verbs in terms of syntactic perspectives .The study also tries to answer the following questions:

1) What are the common syntactic types of phrasal verbs illustrated in Agatha Christie's literary works, namely ('The $\mathrm{ABC}$ Murders'(1936)?

2) What are the functions of the phrasal verbs that emerged in Agatha Christie's 'The ABC Murders'(1936)?

\section{DEFINITION OF PHRASAL VERBS}

Phrasal verbs are a group of verbs which consist of a lexical verb and a particle such as 'go on', 'look at', 'look for', 'point out', etc. Particles are small words which are known as prepositions, adverbs or prepositions and adverbs e.g. about, at, away, back, down, for ,into, on, of, out, in, over, to , and up . (McCarthy \&O’Dell,2004:2).

A phrasal verb, as a type of English verbs , consists of a sequence of a lexical item and one or more particles e.g. (get up, come in ,look outfor, etc). Subtypes of PVs may syntactically be distinguished ,for example, the particles can be divided into adverbial or prepositional types. The definition of 'phrasal' varies somewhat within different descriptions. But the overall syntactic and semantic agreement of these sequences is readily noticeable by using substitution and transformational criteria e.g. :

1- a . She got up at six.

b. She rose at six.

c. What time did she get up? (Crystal ,2008:367).

Phrasal verbs operate more like a phrase than a word. McArthur (1992:774) notes that these verbs are also referred to by other terms such verb phrase, compound verb, discontinuous verb, verb-particle construction, and verb-adverb combination.

Quirk et al (ibid), mention that these structures syntactically and lexically function as a single-word verb ,although they are made up of more than one word.

\section{2- He disposed of the problem.}

Here the sequence (disposed of) behaves as one word .But the word disposed as an item which has variable inflections ('dispose', 'disposing', 'disposed', etc.) remains morphologically a verb .While the items that follow the lexical verb such in (get away, with dispose of, drink up, etc.) are morphologically invariable but have two categories which of adverb and of preposition. So these items can be defined as particles (ibid).

\subsection{Types of Phrasal Verbs}

All grammarians including Quirk et al, (1985: 1152) classify phrasal verbs into two main types :Intransitive and Transitive phrasal verbs .Intransitive phrasal verbs are inseparable while transitive phrasal verbs are subdivided into two subdivisions such as separable and inseparable

\subsubsection{Intransitive Phrasal Verbs}

Phrasal verbs which do not require an object are called Intransitive phrasal verbs as in : 
3- a. The plane has now taken off.

b. They are playing around.

c. Bomb blew up.

Here PVs are composed of a main verb and an adverbial particles.This type of verbs are usually considered informal. There are other similar examples that can be used with particles which are found as prepositions or prepositional adverbs, as in :

4- One of my papers has gone astray.

5- The news made him reel back. (ibid)

These particles can behave as a predication adjunct i.e. they cannot be separated from a lexical verb occurs with:

* The news made him reel distractedly back.

* The bomb blew suddenly up.

Some of PVs are more idiomatic and cohesive than others. However ,the most clear distinction between such phrasal verbs and free combinations is that the meaning of PVs cannot be easily predicted from the meanings of components in isolation e.g. catch on [(understand), give in (surrender) , and blow up (explode).While in free combinations the verb functions normally as a intransitive verb, and the adverb has a consistent meaning. For example :

6- The child walked past. (past the object/place)

7- She waded across. (across the river/water/etc.)

The function of adverbs 'past and across' here likes to that of a prepositional phrase of direction(ibid).

Regarding to the separability, the intransitive phrasal verbs cannot be separated but adverbs can be separated in terms of meaning which can be shown by possible substitutions: In (wade across) for example, (wade) can be substituted by (walk, jump, swim, run, fly, etc.); and the adverb (across) can also be substituted by (over, in, down, up, through , etc) (ibid) .
Another syntactic signs of cohesion. In free combinations, modifying adverbs e.g. 'right' or 'straight' can often be placed between the verb and the adverb particle:

8- a. Go right/straight on.

b. Drink right up.

c. Walk straight in.(ibid)

Alexander (1990 : 157 ) and Redman (1997: 38) state that intransitive PVs cannot be followed by an object i.e. the two parts cannot be separable as in:

9- The children are growing up

\subsubsection{Transitive Phrasal Verbs}

Another type of phrasal verbs which takes an object as mentioned previously by Quirk et al, (1985: 1153) that the phrasal verb which requires a direct object is called a transitive-

phrasal verb, in contrasting with intransitive one .For example:

10- a. We will set up a new unit.

b. I can't make out what he means.

In most transitive phrasal verbs, the particle can be placed either before or after the direct object:

11- a. He turned off the light.

b. He turned the light off. (ibid)

The transitive phrasal verbs are also subdivided into a separable and an inseparable verbs depending of the direct object:

First, if the direct object is a noun ,in this case, the particle is allowed to precede or follow the direct object:

12- a. I have taken off my coat.

b. I have taken my coat off. 
Here the phrasal verb take off is separable. Since the direct object my coat is a noun phrase, it can precede or follow the particle off.

Second, within phrasal verbs ,if the direct object is a personal pronoun, it must be placed between the lexical verb and its particle as in :

\section{3- I switched it off. *- I switched off it.(ibid)}

While Lester,(2009:156) refers to the second set of transitive phrasal verbs i.e. 'Inseparable phrasal verbs' which are sometimes called 'Verb Compounds' consisting of a verb plus a particle which is a preposition, in which prepositions cannot move like an adverb when used in separable compounds, as in :

14 - a. Mary knows about the meeting.

b. John bumped into an old friend today.

c. Mary talked to John.

Lester(ibid) notes even the object is replaced with a pronoun, preposition in the phrasal verb cannot move :

15- Mary knows about it. *_She knows it about.

Quirk et al (ibid: 1154) emphasize that transitive phrasal verbs can generally be turned into passive without stylistic awkwardness as in :

16 - My aunt brought up Mary. _ Mary was brought up by my aunt.

\subsection{Syntactic Features of Phrasal Verbs}

Quirk et al (1972:660) point out that verbs can generally be divided into two types single-word verbs as in (John called the man) and multi-word verbs, which are phrasal verbs as in (Jack called up the boy), prepositional verbs as in(Jack called on the boy), or phrasal-prepositional verbs as in (Jack called up with the boy) .

Quirk et al $(1985,1152)$ divide particles into three groups: Prepositions ,adverbs ,and prepositional adverbs. The third group can be either adverbs or prepositions which are often used with phrasal verbs.
The most obvious difference between the adverbs and the prepositions is that prepositions require a prepositional complement, but there is no such requirement for adverbs.

McCarthy\& O'Dell (2007:6 ) assert that phrasal verbs are extremely used in English i.e. they can be found in various contexts as in songs e.g. Bob Marley's Get up and Red Hot Chili Peppers' Knock me down. They are sometimes used in many newspaper headlines e.g. Cover-up raises fears over bird flu, or in a tittle of film such as The Empire Strikes Back.

Phrasal verbs are very important, so the study attempts to shed light on the syntactic analysis of English phrasal verbs as following:

\subsubsection{Forms}

In addition to Quirk et al (1985) and Rudzka-Ostyn (2003) describe PVs by idiomatic multi-word verbs which consist of a verb combines with an adverb and/or a preposition. Some of them are called prepositional verbs since they consist of a verb plus a prepositionThe possible types and combinations are:

- verb combines with a particle such as : bring up, look into(a murder), put off, slow down, and give away think over

- verb combines with preposition such as: look at, look into (a room), refer to, abstain from, depend on, and think of.

- verb plus a particle+ a preposition such as : get down to, face up to, be in for, come up with.

Phrasal verbs consist of two parts : a verb plus an adverbial particle ,as indicated by (Quirk et al 1985:1150), as in:

\section{7- The plane took off.}

According to Palmer(1987:215), in some combinations, there is a limited number of particles can combine freely with verbs, while others are collocational combined with limited verbs e.g. look after , afraid of, etc. 


\subsubsection{Transitivity}

Halliday ( 1994:168) emphasizes that there are three elements which help the reader to discover the world view of the writer or the persona in a literary works .The elements are Process, Transitivity, and Participants .

Regarding to the transitivity feature ,PVs can be divided into two types : intransitive or transitive :

\section{8- What time does Bob usually get up in the morning?}

19- a. He switched off the light.

\section{b. He switched the light off.}

The phrasal verb in (18) is an intransitive i.e. with no object but in $(19 \mathrm{a}, 19 \mathrm{~b})$ it is a transitive i.e. it is followed with a noun as a direct object .

Downing \& Locke(2006:60) also agree Quirk et al(1985) identifying that PVs are divided into two types (transitives and intransitives ), but some of them can be used both transitively and intransitively, e.g. 'blow up' means (explode), 'break down' means( reduce to pieces):

20- The terrorist has blown up the train station. (transitive)

\section{1- The train station has blown up. (intransitive)}

\subsubsection{Separability}

Quirk et $\mathrm{al}(1985)$ and Lester (2009:154) note that intransitive phrasal verbs are inseparable,

while the transitive phrasal verbs can be separable or inseparable. A phrasal verb is separable, it means the two elements can be separated and putting the direct object in the middle as in (22a) , and it may be inseparable as in(22b):

\section{2- a. He switched the light off.}

\section{b. He switched off the light.}

Lester(ibid)considers a phrasal verb as an idiomatic combination whose meaning is generally unpredictable. Lester(ibid)also emphasizes that ,phrasal verbs can be subdivided into separable and inseparable according to their transitivity ,in other words ,if phrasal verbs are intransitives ,they cannot be separable ; But transitives are separable as in :

23- The manager called off the meetings. $\sim$ The manager called the meeting off.

\subsubsection{Position of Particles}

Leech (2006) andDowning \& Locke(2006) argue that the particle may precede or follow the object when the object is a noun ;But when the object is a pronoun and the particle must be placed after it .

\section{4- He switched it off. *_He switched off it.}

In order to emphasize new information, the object as a noun is placed after the particle as in (25b), whereas pronouns do not usually represent new information, so they are used before the particle as in (24)(ibid).

Eastwood (2002:303) asserts this order depends on what is the point of interest. For example:

25- a. We woke up the neighbours.

b. We woke the neighbours up .

Here the point of interest, in (25a), is the object 'the neighbours, ,Whereas in (25b) is the action of the phrasal verb 'woke up'. In other words, when the particle follows the object, this order gives extra emphasize to the adverb, especially which refers to movement.(ibid)

McArthur (1992:773) argues that English adverbs have various positions . However, they can be often appeared together with the particles of phrasal verbs. Within intransitive phrasal verbs, adverbs may occur in different positions, as following :

26- a. I happily ran away.

b. I ran happily away.

c. He ran away happily.

Whereas with transitive phrasal verbs as an adverb occurs either before the verb or after the particle or object: 
27- a. He eagerly picked the letter up.

b. He picked up the letter eagerly.

c. He picked the letter up eagerly.

But there is no sentence in most contexts such as :

- *He picked the letter/it eagerly up. (ibid)

While Palmer (1987:223) argues that some combinations do not allow the particle (an adverb) to precede the verb, this can simply be exampled in:

28- Mary cried her eyes out. *_ Mary cried out her eyes.

\subsubsection{Extension}

Palmer (1987:224) mentions that the extension means the use of different lexemes with same syntactic and semantic relationships .Some phrasal verbs can be identical with transitive combinations ,but the object can be understood whether be added or deleted as in :

30- a. They carried on .

b. They carried on the business.

Murphy( 2012:278) indicates that phrasal verbs are sometimes followed by a preposition and/or an object. For example:

31- Why did you run away from me? You're walking too fast.

32- I can't keep up with you. Are you looking forward to your trip?

\subsubsection{Passivity}

PVs on passivizing e.g. He blew up is fine, but not*he was blown up by what I said. Rudzka-Ostyn (2003:1) points out that PVs are used in the passive if there is a flow of energy from an agent to an object e.g. The bill was made up in a minute is fine, but not ${ }^{*}$ His mind was made up in a minute.

Not just a single-word verbs can be passive, many PVs can also be passive, for example:

33- The rest of the food was thrown away.
34- The alarm has been switched off. (Eastwood ,2002:304).

Quirk et al (1985:1167) point out that some combinations such as (be ran down) and (be fed up) are used only with passive PVs but cannot be with the active as in:

35- He was fed up with the noise. *- The noise fed him up.

\subsubsection{Complementation}

Newson et al (2006:188) emphasize that phrasal verbs do not function like a verb which

takes a prepositional phrase (PP) complement .Thus, the two types of verb can be distinguished in some ways:

36- a. He took off his coat - He took his coat off.

b. He lived in a flat *_He lived a flat in .

37- a. In this flat, he lived for five years .

b. *Off this coat, he took in an instant.

38- a. He lived right near a forest.

b. ${ }^{*}$ He took right off his coat .

39- a. He lived near the mountain and next to a river.

b. ${ }^{*}$ He took off his coat and off his hat.

According to the above, there is an indication asserts that the prepositions do not function as the head of the phrase, but form a unit with verb. For example, the prepositional phrase (PP) complement of a verb in (36a) can be moved to the front of the clause, this means that the particle and its following phrase cannot be moved as in (36b), showing that it is perhaps not a constituent. Furthermore, a PP in (38a) can be modified by an adverb like 'right', but this is not possible for the particle followed by a PP (38b).

Finally, a preposition phrase complement can be coordinated with another PP (39a), but it is not possible to be applied (39 b), indicating that the particle does not form a PP with the following PP. (ibid :190). 


\subsubsection{Syntactic Features of Particles}

Some syntactic features of particles have been determined by McCarthy\& O'Dell (2004:10 ) saying that particles in some transitive phrasal verbs can be placed as in following:

a) Some particles must precede the object of phrasal verbs as in :

40- She is looking for her keys. *-She is looking her keys for.

b) Some particles must follow the object of phrasal verbs as in:

41- a. We have a lot of work on .

b. We have on a lot of work .

c) Some particles can precede or follow the object of phrasal verbs as in :

42- a. The thunder woke up the child.

b. The thunder woke the child up.

Sroka (1972:36) classifies the particles of PVs to three kinds: Adverbs, Prepositions, and Adverb-Preposition words.

\subsection{Importance of Phrasal Verbs}

Regarding to the number of English PVs as stated by Praninskas (1957:217) that there is no one can account the number of PVs in English but it is very large. Indeed the number of them very important for the people who are specialized in English ,especially with those which are frequently used whether in written or spoken English language.

Many Grammarians including McArthur (1992) note that phrasal verbs are used both literally and metaphorically. They are often idioms or parts in idioms such as: to get on like a house on fire, to get away with murder, to get up to mischief, to get back at someone.

The idiomatic usages of phrasal verbs in everyday speech makes them so important. In addition, some phrasal verbs have very ambiguous meanings. Some phrasal verbs are used in context, but no one can know their meaning unless looking their meanings up in the dictionary or in any book on idioms(ibid).

McCarthy\& O'Dell (2007:6 ) point out that phrasal verbs are extremely used in English, so many combinations which be recognized as lexical verb plus an adverbial particle e. g: take back, get up, sit down ,switch on/off, can be found in various contexts, for example in songs e.g. the Beatles' I'll get by with a little help from my friends, Roll over Beethoven, or Red Hot Chili Peppers' Knock me down.

In addition to McCarthy and O'Dell (ibid) such as Gardner and Davis (2007) agree that PVs play a vital role in linguistics, most students seem to avoid using them regularly. And several studies have assumed that PVs are found in informal and spoken English language, many researchers such as emphasize that PVs are largely used in written and formal English. Additionally, Fletcher (ibid) mentions that PVs are also used in several types written texts including the literary texts . As an effective tool ,PVs play an important role to convey the writer's messages. Chen (2007: 350) emphasizes that native speakers use PVs frequently according to their "characteristics of flexibility, practicability, adaptability and efficiency". While nonnative speakers face difficult to acquire them owing to the permeability (Tu \& Thao, 2018:115) .

\subsection{Synonym of Phrasal Verbs}

Palmer(1987:216), McCarthy\&O’Dell (2004:8) note a phrasal verb can be replaced by a single-word verb e.g. come in 'enter', give in 'yield', and look after 'tend'. Like single- word verbs, some phrasal verbs have multiple meanings, this case is illustrated by McCarthy\& O'Dell ( $2004: 14$ ) as in the following examples :

43- He got on bus. ( he entered the bus )

44- Oh! I'm trying to get on with my work. ( continue doing my work )

45- Jim and Ian get on really well . (they like each other and friendly ) 
Here 'get on' has various meanings i.e. there is no direct connection between its meanings. Most phrasal verbs have core meanings .

\subsection{Three-Words Phrasal Verbs}

Phrasal verbs as previously mentioned that they consist of two part but sometime they can be formed from three parts as indicated by Hart (2017: 30) when he says that PVs can be consisted of three words e.g. 'feel up to' 'looking forward to', 'get over with', etc. Threewords phrasal verbs are combinations of a verb, a particle, and a preposition, respectively. This type of verbs is always transitive and most of them are inseparable as in.

46- It's been a long day, I know, but do you feel up to playing tennis after dinner?

47- It was nice to meet your father, and I look forward to seeing him again.

But some three-word phrasal verbs are separable because they need two objects:

48-Mr. Baker tried to screw his ex-wife out of her share of the lottery prize.

The PV 'Get over with' for example, is formed of threeword which be always separated, but it is intransitive as in:

49- Everyone our class must make a presentation.I am very nervous about it, so I want to go first so I can get it over with and relax.

While 'go along with' cannot be separated wherever it occurs:

50- I understand your concern, Tom, but I have to go along with Linda on this matter.

51- What's my opinion? I go along with John(ibid) .

McCarthy\& O'Dell ( 2004: 16) emphasizes that not only with formal the three-word verbs can also be used with informal . Monkey around with, for instance, is informally used when adjusting or trying to repair mechanical devices even though no having permission or skill to do.
52- Jack monkeyed around with his printer, and I think maybe he fixed it.

53- Lara was monkeying around with her camera, and now it doesn't work. (ibid)

An adverb in sentences of three-word phrasal verbs ,is sometimes possible included, but it may be problematic: First, an adverb is sometimes acceptable to be placed between the verb and first particle and other times it does not. Second, an adverb can sometimes be placed between the two particles and other times it cannot. This matter is more stylistic than of what is correct or incorrect as in:.

55- a. Eventually, I grew out of the sweater.

b. He eventually grew out of the sweater.

c. I grew out of the sweater eventually.(ibid)

\subsection{Prepositional Verbs}

All grammarians describe prepositional verbs as a combination of a verb plus a preposition .Swan, (1980 :491) defines the term of prepositional verbs as "a large number of combination of verb + preposition". Quirk et al (1985:1155) indicate that prepositional verbs refer to a type of multi-word verbs which consists of a main verb combines with a preposition, and these elements are syntactically and semantically associated with each other e.g. 'look at' ,'cope with' ,'go into' ,etc. The preposition within a prepositional verbs must precede its complement as in :

56Look at this picture.

57- You can cope with the study.

58- You have to go into the problem.

Here in above examples, the main verbs are followed by particles which are clearly prepositions precede complements. However, the second noun phrase ,in below sentence, cannot be considered the direct object of the lexical verbs look at but the complement the preposition at (ibid):

59- Many people looked at the paintings.

While in other constructions, the second noun phrase is called prepositional object as in: 
60- Some people examined disdainfully with the pictures.

Quirk et al(1985:1156) attempt to avoid the ambiguity using the term 'prepositional verbs' that can be shown in the following complementary analyses :

Analysis 1: $\quad \mathrm{S} \quad \mathrm{V} \quad \mathrm{A}$

She looked after her boy.

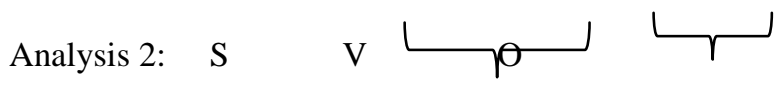

According to the first analysis ,the verb look is intransitive, whereas in another analysis, the verb 'look after', which means tend, is a transitive takes an object(ibid).

In prepositional verbs e.g. 'look for', 'look at', etc The lexical verb usually keeps a literal use and associated with fixed a preposition. In some prepositional verbs such as ' $g o$ into', the two elements semantically form an idiomatic combination. Whereas other sequences of a verb plus a preposition e.g. 'live at', are obviously nonidiomatic or free combinations(ibid).

\subsection{Overlapping of Phrasal Verbs and Prepositional Verbs}

Grammarians such as Quirk et al (1985) and Palmer(1987) point out that prepositional verbs are paralleled by phrasal verbs because both of them are formed from two parts. However, they attend to illustrate how phrasal verbs are contrasted with prepositional verbs.

According to Quirk et al (ibid:1156) PVs consist of a lexical verb plus particles which can be an adverb or a preposition. While a prepositional verb is formed just from a verb and a preposition as in :

61- The plane has just touched down .(a phrasal verb)

62- He called on his friends. (a prepositional verbs)
The preposition of prepositional verbs cannot follow the phrasal noun in a sentence as in:

63- He called on his friend.*-He called his friends on.

Whereas a particle can move to a position after the noun phrase as in:

64- I switched of the light . I switched the light off.

Likewise, the case of particles and pronouns is different, in other words, the particle of transitive phrasal verbs must follow the object which is a pronoun; But with prepositional verbs do not:

65- He called on them .*_ He called them on.

66- I switched it on .*_ I switch on it .(ibid)

According to the ending preposition there is a view which claims a preposition cannot occur at the end of a sentence i.e. the sentence cannot end with a preposition :

\section{7- Did you look the word up?}

Here the particle 'up' is not a preposition but a second part of the verb "look up" . Kolln \& Funk (2012:294) refuted this view, noting that a little word which occurs at the end may be a preposition , especially in a question:

68- Who shall we talk to? (i.e., To whom shall we talk?)

According to the distinguishing between "PVs" and "Pre Vs", Dixon (1992:270) also distinguishes between the verbs which cannot be used without a particle and those which can occur with or without the particle. Dixon refers to the verbs that never occur without the particle a single lexeme. While PVs, on the other hand, consist of a verb plus a preposition an create a meaning different from that of the verb alone.

So the differences between phrasal verbs and prepositional verbs can be shown in table (2.1)below. 
Table (2.1) The difference between PVs and Pre-Vs

(Quirk et al (1985:1167).

\begin{tabular}{|c|c|c|}
\hline Items & Phrasal verbs & Prepositional verbs \\
\hline 1 & $\begin{array}{l}\text { Phrasal verbs can defined as combinations of a lexical } \\
\text { verb and particles which can be an adverb ,preposition or } \\
\text { both e.g. go on, go away, get over with, etc. As in: Go on, } \\
\text { he knows what you mean. }\end{array}$ & $\begin{array}{l}\text { Prepositional verbs are formed just from a verb and a } \\
\text { preposition e.g. go to, look at. etc. As in: } \\
\text { I go to the school every day. }\end{array}$ \\
\hline 2 & $\begin{array}{l}\text { The particle may precede or follow a direct object which is a } \\
\text { noun phrase. As in : 'He took off his coat' or 'He took his } \\
\text { coat off' }\end{array}$ & $\begin{array}{l}\text { Prepositions have to come before the direct object. As in: } \\
\text { 'He called on them'. } \\
\text { * 'He called them on'. }\end{array}$ \\
\hline 3 & $\begin{array}{l}\text { If the object is a noun phrase ,it can precede or follow the } \\
\text { particle, but in the case of a pronoun, it must place between a } \\
\text { verb and its particle. As in: 'I want to find out the fact' or 'I } \\
\text { want to find the fact out' }\end{array}$ & $\begin{array}{l}\text { A direct object, whether a personal noun or a noun phrase, } \\
\text { must come after the particle i.e. it comesbetween a verb and } \\
\text { its particle. As in 'I looked at the pictures' }\end{array}$ \\
\hline 4 & $\begin{array}{l}\text { An adverb ,as adjunct, cannot insert between a verb and its } \\
\text { particle within phrasal verbs. }\end{array}$ & $\begin{array}{l}\text { An adverb can be inserted between a verb and a preposition } \\
\text { in the case of prepositional verbs. }\end{array}$ \\
\hline 5 & $\begin{array}{l}\text { A relative pronoun cannot follow the particle of a phrasal } \\
\text { verb at the beginning of relative clause ,as in : 'She takes it } \\
\text { off', "'She takes off it' }\end{array}$ & $\begin{array}{l}\text { The preposition of the prepositional verb can precede a } \\
\text { relative pronoun at the beginning of a relative clause , as in } \\
\text { :'You can call on him' }\end{array}$ \\
\hline 6 & $\begin{array}{l}\text { Phrasal verbs can be idiomatic, semi-idiomatic, or non- } \\
\text { idiomatic combinations i.e. their meanings cannot be easily } \\
\text { inferred from the meaning of their parts. }\end{array}$ & $\begin{array}{l}\text { Prepositional verbs are literal combinations only i.e. the } \\
\text { meaning can be inferred from the individual meaning of } \\
\text { their parts }\end{array}$ \\
\hline
\end{tabular}

\subsection{Phrasal Verbs and Other Categories}

Hart (2017), McCarthy \&O’Dell (2007) ,Palmer (1987) and others point out that (PVs) do not represent verbs only, such as 'make up' ;But they can also be used as a noun e.g. 'makeup' or an adjective e.g. 'made-up'. This means in English many nouns and adjectives can be created basing on phrasal verbs with or without a hyphen .

\subsubsection{Phrasal Verbs and Nouns}

Hart (2017:78) points out that many of (PVs) can be used as nouns, such nouns are written as one word as in Lay off (v.) layoff (n.)or two words separated with a hyphen e.g. Go ahead (verb) go-ahead (n.)
Hart (ibid) asserts, that there is no a rule to indicate which a noun must be hyphenated and which should be written as one word.

McCarthy \&O'Dell (2007:10) emphasizes that phrasal nounsare alike phrasal verbsin their forming i.e. both of them consist of a verb and a particle. The particle may precede or follow the verb e.g. standby, letdown, onset ,etc. This can be simply exemplified as in:

69- My father is a pilot and he is on standby over the weekend.

70- Neil can provide technical back-up if you need it.

According to the plural of nouns which are derived from PVs , McCarthy \&O'Dell (2004:12) note that 
plurality of these nouns is formed by adding (-s) plural to the particles not to the verbs such as:

$$
\begin{array}{ll}
\text { 71- Break-in } \sim \text { break-ins } & * \sim \text { breaks-in. } \\
\text { 72- Dropout } \sim \text { dropouts } & * \sim \text { dropsout. }
\end{array}
$$

But there is an exception with a noun 'going-on', in which $(-$ s plural $)$ is added to the verb not the particle as in :

73- There is a lot of gossip about the goings-on at the office party.(ibid)

\subsubsection{Phrasal Verbs and Adjectives}

Many adjectives are also formed from the construction of PVs like 'a broken-down bus'( a bus whose engine has stopped working), ongoing problem (a problem which continues), etc .However, it can be said that some adjectives are related to English PVs in their forming (McCarthy \&O'Dell (2007:12) :

74- He has an ongoing problem with the computer system.(a problemwhich continues)

75- I was wearing old, worn-out shoes.(weak, damaged through much use).

Hart(2017:122) mentions that adjectives are participle i.e. they are derived from(PVs). Some participle adjectives are written as one word e.g. 'rundown', or written with/without a hyphen e.g. 'makeup'and 'fixed up'. There is a rule followed to show which a participle adjective has to be hyphened and which not to be.

Hart(ibid:84) states that nouns which are derived from (PVs) can combine with an ordinary noun to create compound nouns such as :

- A noun:backup a compound noun:backup disk

- A noun:follow-up a compound noun:follow-up call

The first noun of new compound nouns functions like an adjective in an ordinary compound nouns as in :

76- Jack: What kind of clothes?

Bob: Dirty clothes. (dirty is adj.)
Jack: What kind of clothes?

Bob: Workout clothes. (workout is $\mathrm{n}$.)

Here the adjective 'dirty' and the noun 'workout' have the same function which modifies the noun 'clothes'.

\subsubsection{Phrasal Verbs and Collocation}

McCarthy \&O'Dell (2007:10) define collocation as "the way words combine with one another". So ,it is very important to know which words a verb has to use with.

According to collocation, Palmer (1987:215) notes that there is a limited number of particles in some combinations can combine freely with some verbs .On the other hand, some particles within phrasal verbs are collocational combined with limited verbs e.g. look after , afraid of, etc.

Seidl \&McMordie( 1988:100) identify that a particular difficulty which faces most non-native speakers of English is how the phrasal verbs are used , and which verbs consisting in a combination with a particle or a preposition e.g. 'give in'. Some combinations of verbs and an adverb or a preposition have fully idiomatic meanings i.e. the meaning of a combination is completely different from the individual meanings of the a verb and a particle as in:

77- He decided to pick his job in.

The meanings of 'pick' and 'in' do not bear the exact meaning (leave or abandon)(ibid).

Some combinations of a verb plus a preposition or an adverb may have more than one idiomatic meaning depending on the particle which combines with i.e. there is a collocation(ibid).

McCarthy \&O’Dell (ibid:10) mention that knowledge of a verb and its collocation will help speakers to speak and write more precisely. Some collocations with objects ,for example, denoting people or things as in :

78- a. I would advise you to keep in with the boss/ James 
* b.I would advise you to keep in with the exam system.

Some collocations with subjects denoting people or things as in:

79- a. John has to dashed off. He has a meeting in 30 minutes.

\section{b.*The car dashed off along the motorway(ibid).}

Barlow and Burdine (2006:3) state that "each meaning of a phrasal verb is usually associated with a set of particular words (collocates) within the sentence". This can be more simplified in other word e.g. the word 'complaints' is associated with the phrasal verb 'deal with' i.e. it is a collocate of deal with, as in:

80- He had to deal with a lot of complaints.

\section{DATA COLLECTION}

One of Agatha Christie's novels was adopted as a data for the syntactic analysis of PVs in this paper. The novel belongs to the detective genre which is entitled 'The ABC Murders'(1936). The researchers see that the analysis will be very bulky if the wholechapters of the novelare analysed, so some selected chapters from the novel have been chosen for the analysis.The researchers attempt to debate the term of Phrasal Verbs through 'more and better' impact data by highlighting experience on combining quantitative and qualitative analysis which serves the present paper.

From this discussion it can be realized that both qualitative and quantitative analyses have an effective contribution for literary studies. Kandilji \& Al-Samarrai (2009 :66) state that the qualitative research is considered a basic methodology to enrich descriptive goals, while the quantitative one focuses on an experiment and discovering cause and result which based on specific variable measures and numerical data.

\subsection{Agatha Christie(1890-1976)}

Agatha Christie is a British writer who was born in Torquay in 1890 . She has many literary works e.g. novels , plays, short stories ,and poems and other books which were translated into 45 languages . She is considered the best-selling author of all time. She wrote eighty criminal novels so she is considered the best criminal novelist in the world .Christie did not write detective novels only, but she wrote six romantic novels (Cawthorne,2014:5).

Christie wrote more than eighty crime novels thus she is also considered as the best criminal novelist and she is called the queen of detective fiction(Collins, 1936:5).

There is an overlapping between the terms "crime fiction" and "detective fiction" which are usually used interchangeably. To make a distinction between the two genres it can be said that crime fiction is considered the umbrella term for crime in general on one hand, while the detective fiction is mainly concerned with the process of detection.( Vurmay,2017:1128)

According to selling of Christie's books, more than two billions copies of her literary works have been sold, so she is considered the best-selling novelist for all time (Kastan, 2006:467).

Christie has created the two enduring characters in her detective literature 'Hercule Poirot' and 'Miss Jane Marple' (ibid) .

Detective genre which sometimes called a mystery genre is a special literary genre. This literary genre is usually associated with the labyrinthine plot, it is also related with strong logic sense as well as the high suspenseful situation and setting.(Zhang,2001:146)

The 1920s and 1930s are considered the Christie's golden age in which she wrote many of her masterworks including 'The ABC Murders' (1936) (ibid).

Christie is undoubtedly considered the lady of complexity in plotting but she was distinguished by her simple style in writing of her literary works which are characterized by a simple and clear language .In addition to that, she draws her characters with the finest touches and she injects her thoughts and feelings into her works so that readers can read it Easily(ibid)

Coulthard(1985:179) emphasizes that "Linguistic study remains rare in this area. However,considering the fact that literature is the art form realized entirelythrough language, it is reasonable to suggest that a detailed 
analysisof authorial technique and stylistic features can be more successfullyachieved within a rigorous linguistic framework"

Gale (2016) points out that Christie uses a first person account in 'The ABC Murders' (1936) which is told by Captain Hasting who is the best friend of Hercule Poirot. Hasting is not directly related to the case at all but he has a captivation with his Poirot's personality. This explains that Hasting is not an objective observer (ibid).

Christie wrote not only in detective genre but she also wrote six romantic novels under the pseudonym 'Mary Westmacott'. She died in 1976 in Wallingford(Cawthorne, ibid).

\subsection{Summary of the Detective Novel 'The ABC Murders' (1936)}

The ABC Murders is one of Agatha Christie's detective novels which has been published in UK in 1936. In this novel, the author gives a genius presentation of how to confront the intelligence of the criminal murderous with the intelligence of the investigator Poirot and how Poirot's intelligence managed to conquer the killer's intelligence according to the alphabet i.e. that this novel is a true struggle between crime and justice. The strategies of killing are done according to the alphabetical order (Kodirova, 2020:187).
Christie creates an enduring character called Hercule Poirot who received letters signed by A.B.C. Each one of these letters includes the place and date of the next murder .The first victim is Allce Ascher who was killed in her tobacco shop in Andover after Poirot received a letter signed by $\mathrm{ABC}$ directing him to Andover in which the first murder was killed .About a month after Alice's murder, $\mathrm{ABC}$ sent another letter to Poirot telling him about the second murder 'Betty Barnard' who was a waitress killed in Bixhill. The third victim was a rich man called Sir Carmichael Clarke who was killed in his home.

At the end of her novel, Christie showed that Poirot explores that the ABC killer is Cust(ibid).

\section{3 The Modal of the Analysis}

The present paper adopts Quirk et al.'s (1985) classification of PVs as a model of analysis which systematizes the concept of PVs by classifying them syntactically into two main categories: Transitive andIntransitive. 'Intransitive Phrasal Verbs' are always Inseparable verbs while 'Transitive'are classified into two subcategories: Separable and Inseparable. These types can provide a practical means for describing and analyzing various types of phrasal verbs which are used in Agatha Christie's “The ABC Murders". See figure (3.1).

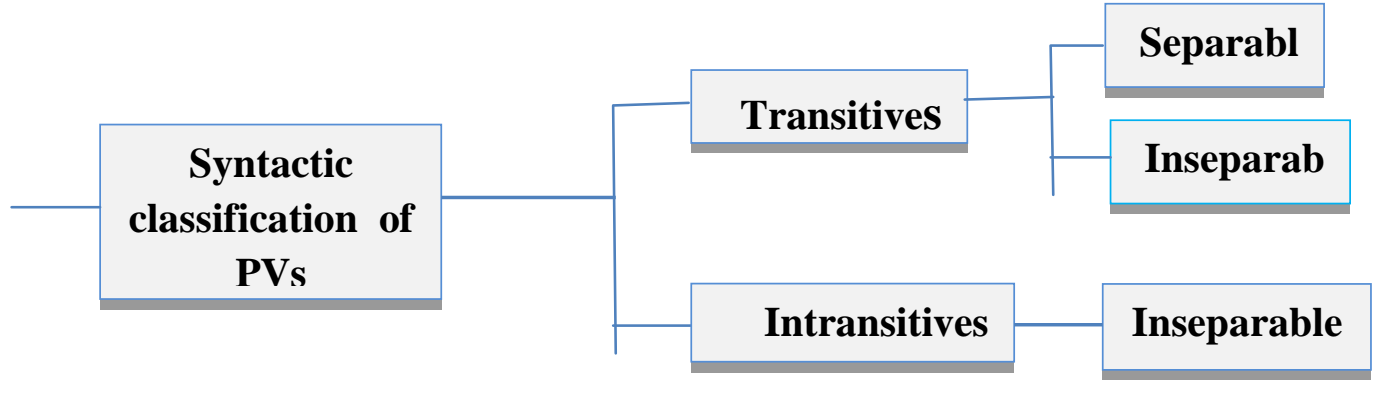

Figure (3.1)The Syntactic Classification of Phrasal Verbs(Quirk et al,1985:1152) .

\section{DATA ANALYSIS}

Data analysis is presented in the form of tables. The tables include the syntactic classifications of PVs - 'Intransitives' and 'Transitives', the intransitives always are 'Inseparable' while the transitives are subdivided into two types 
:Inseparable and Separable . Each bold verb in the tables shows the PVs in the original text of Agatha Christie's 'The ABC Murders' (1936). Page numbers are also included in the tables in order to give accuracy to the analysis .

\subsection{The ABC Murders (1936)}

The main characters :

- Hercule Poirot who is the investigator who received the letters which are signed by A.B.C. murder ,and who explores the real killer at the end.

- Allce Ascher who is the first victim who was killed in her tobacco shop in Andover.

- Betty Barnard who is the second victim who was a waitress killed in Bixhill.

- Sir Carmichael Clarke who is the third victim who was a rich man that killed in his home.

- Alexander Bonaparte Cust who is the ABC killer.

\subsubsection{Data Analysis of 'The ABC Murders' (1936)}

In table(4.1), details of the syntactic descriptions of PVs are mentioned concerning the detective novel 'The $\mathrm{ABC}$ Murders' (1936) under study. The table comprises some examples selected from the novel that includes PVs besides the type of these verbs.

To give accuracy to the study, page numbers are also included in the table. The choice of being phrasal verbs are Transitive/ Intransitive, Separable/ Inseparable has marked by tick symbols in the table below :

Table (4.1)The Syntactic Analysis of Phrasal Verbsin'The ABC Murders' (1936)

\begin{tabular}{|c|c|c|c|c|c|}
\hline \multirow[t]{3}{*}{ Items } & \multirow[t]{3}{*}{ Example } & \multirow[t]{3}{*}{ PVs } & \multicolumn{3}{|l|}{ Types of PVs } \\
\hline & & & \multirow[t]{2}{*}{ Intransitive } & \multicolumn{2}{|l|}{ Transitive } \\
\hline & & & & Separable & Inseparable \\
\hline 1. & $\begin{array}{l}\text { REVIVIT .To bring back the natural tone of the hair. } \\
\text { (P.9) }\end{array}$ & bring back & - & - & $\checkmark$ \\
\hline 2. & $\begin{array}{l}\text { He was coming to London and would call upon } \\
\text { Poirot.(P.150) }\end{array}$ & call upon & - & - & $\checkmark$ \\
\hline 3. & $\begin{array}{l}\text { I could not imagine Ascher inventing and carrying out } \\
\text { such an elaborate scheme. (P.288) }\end{array}$ & carrying out & - & - & $\checkmark$ \\
\hline 4. & He came slowly across to me.(P.12) & Come across & - & - & $\checkmark$ \\
\hline 5. & The clue of the stockings came into my hands.(P.283) & Come into & - & - & $\checkmark$ \\
\hline 6. & "But then I came up against a definite difficulty. (P.285) & Come up & $\checkmark$ & - & - \\
\hline 7. & $\begin{array}{l}\text { The murderer could have done away with them without } \\
\text { incurring any suspicion. (P.280) }\end{array}$ & do away & $\checkmark$ & - & - \\
\hline 8. & Possibly he dozes off for a minute or two .(P.296) & dozes off & $\checkmark$ & - & - \\
\hline 9. & Everything fell out well. (P.295) & Fall out & $\checkmark$ & - & - \\
\hline 10. & I shall be able to find out who he is.(P.146) & Find out & - & - & $\checkmark$ \\
\hline 11. & $\begin{array}{l}\text { "Naturally that I do not know or I should not want to find } \\
\text { out! (P.149) }\end{array}$ & Find out & - & - & $\checkmark$ \\
\hline 12. & $\begin{array}{l}\text { I would not want much wages, but only to find out who } \\
\text { this awful fiend is. (P.150) }\end{array}$ & Find out & - & - & $\checkmark$ \\
\hline 13. & A.B.C. could not much longer hope to get away with his & Get away & $\checkmark$ & - & - \\
\hline
\end{tabular}




\begin{tabular}{|c|c|c|c|c|c|}
\hline & crimes.(P. 283) & & & & \\
\hline 14. & $\begin{array}{l}\text { He must able, as you English say, to get off. } \\
\text { ( P.282) }\end{array}$ & Get off & $\checkmark$ & - & - \\
\hline 15. & When he got up to go, you did the same. (P.295) & Get up & - & - & $\checkmark$ \\
\hline 16. & Here the murderer goes back to his first method.(P.282) & Go back & $\checkmark$ & - & - \\
\hline 17. & $\begin{array}{l}\text { He has no need to go into them minutely his experience. } \\
\text { (P.278) }\end{array}$ & Go into & - & - & $\checkmark$ \\
\hline 18. & As I looked rather bewildered, he went on. (P.147) & Go on & $\checkmark$ & - & - \\
\hline 19. & He went on. (P.287) & Go on & $\checkmark$ & - & - \\
\hline 20. & Fraser's eyes went toward Megan. (P.300) & Go toward & - & - & $\checkmark$ \\
\hline 21. & $\begin{array}{l}\text { I learnt something of her character a picture grew up in } \\
\text { my mind. (P.282) }\end{array}$ & grew up & $\checkmark$ & - & - \\
\hline 23. & I handed it back to him.(P.12) & Hand back & - & $\checkmark$ & - \\
\hline 24. & The A.B.C. terror taken hold on the public mind. (P.294) & Hold on & - & & $\checkmark$ \\
\hline 25. & $\begin{array}{l}\text { "Do you suspect them of keeping things back, then?" } \\
\text { (P.148) }\end{array}$ & Keep back & - & $\checkmark$ & - \\
\hline 26. & $\begin{array}{l}\text { "You had now to look about for two victims whose } \\
\text { names began with A and B respectively.(P.293) }\end{array}$ & Look about & - & - & $\checkmark$ \\
\hline 27. & $\begin{array}{l}\text { There was something so odd about his tone that I looked } \\
\text { at him in surprise. (P.11) }\end{array}$ & Look at & - & - & $\checkmark$ \\
\hline 28. & I looked at him curiously.(P.12) & Look at & - & - & $\checkmark$ \\
\hline 29. & My friend looked at me dispassionately. (P.146) & Look at & - & - & $\checkmark$ \\
\hline 30. & $\begin{array}{l}\text { He cast a sudden appealing look at the other man. } \\
\text { (P.292) }\end{array}$ & Look at & - & - & $\sqrt{ }$ \\
\hline 31. & $\begin{array}{l}\text { I think, to go and look at the place where the crime was } \\
\text { committed. (P.297) }\end{array}$ & Look at & - & - & $\checkmark$ \\
\hline 32. & Poirot looked at me in mild surprise. (P.299) & Look at & - & - & $\checkmark$ \\
\hline 33. & She looked at him and her colour deepened. (P.300) & Look at & - & - & $\checkmark$ \\
\hline 34. & The faces that looked at him were blank too. (P.285) & Look at & - & - & $\checkmark$ \\
\hline 35. & He stopped, looking at Poirot inquiringly. (P.285) & Look at & - & - & $\checkmark$ \\
\hline 36. & $\begin{array}{l}\text { He loses his nerve, fancies his landlady is looking at him } \\
\text { suspiciously. (P.296) }\end{array}$ & Look at & - & - & $\checkmark$ \\
\hline 37. & $\begin{array}{l}\text { "In Betty Barnard you found just the type of girl you } \\
\text { were looking for. (P.293) }\end{array}$ & Look for & - & - & $\checkmark$ \\
\hline 38. & You're looking in fine fettle, Poirot. (P.8) & Look in & - & - & $\checkmark$ \\
\hline 39. & $\begin{array}{l}\text { Look out for Andover on the } 21 \mathrm{st} \text { of the month. } \\
\text { ( P.12) }\end{array}$ & Look out & $\checkmark$ & - & - \\
\hline 40. & $\begin{array}{l}\text { I need hardly say that one of my first actions on reaching } \\
\text { England was to look up my old friend. (P.7) }\end{array}$ & Look up & - & - & $\checkmark$ \\
\hline 41. & $\begin{array}{l}\text { The matter had passed completely out of Miss Grey's } \\
\text { head. (294) }\end{array}$ & Pass out & - & - & $\checkmark$ \\
\hline 42. & "I will pass over the next stages quickly. (283) & Pass over & - & - & $\checkmark$ \\
\hline 43. & He passes it playfully round her neck.(282) & Pass round & - & - & $\checkmark$ \\
\hline 44. & $\begin{array}{l}\text { Your photograph was picked out from half a dozen } \\
\text { others by two people. (P.298) }\end{array}$ & Pick out & - & - & $\checkmark$ \\
\hline
\end{tabular}




\begin{tabular}{|c|c|c|c|c|c|}
\hline 45. & $\begin{array}{l}\text { He shook his head, and picking up the letter, put it away } \\
\text { again in the desk.(P.13) }\end{array}$ & Pick up & - & - & $\sqrt{ }$ \\
\hline 46. & $\begin{array}{l}\text { He picked up a railway guide and consulted it, then he } \\
\text { returned to the consideration of a typewritten list of } \\
\text { names. (P.15) }\end{array}$ & Pick up & - & - & $\checkmark$ \\
\hline 47. & He picked up another letter. (P.150) & Pick up & - & - & $\checkmark$ \\
\hline 48. & $\begin{array}{l}\text { The attractive free and easy manner nothing easier for } \\
\text { him than to pick up a gift in a café. (P.289) }\end{array}$ & Pick up & - & - & $\checkmark$ \\
\hline 49. & "I put that in to please you, monami."(P.301) & Put in & - & $\checkmark$ & - \\
\hline 50. & You enjoyed scoring off a foreigner .(P.294) & Score off & - & - & $\checkmark$ \\
\hline 51. & $\begin{array}{l}\text { I had various affairs to see to in England that I felt could } \\
\text { only be successful if a personal touch was introduced. } \\
\text { (P.7) }\end{array}$ & See to & - & - & $\checkmark$ \\
\hline 52. & You sent off the first A.B.C. letter to me. (P.293) & Send off & - & - & $\checkmark$ \\
\hline 53. & I set it down with as much confidence on paper. (P.269) & Set down & - & $\checkmark$ & - \\
\hline 54. & $\begin{array}{l}\text { Mr. Cust in the darkened doorway, wiping the knife on } \\
\text { his sleeve and slipping it into his pocket.(P.295) }\end{array}$ & Slip into & - & $\checkmark$ & - \\
\hline 55. & Donald Fraser sprang up. (P.282) & Spring up & $\checkmark$ & - & - \\
\hline 56. & She takes it off.(P.282) & Take off & - & $\checkmark$ & - \\
\hline 57. & $\begin{array}{l}\text { You took her out once or twice, explaining to her. } \\
\text { (P.292) }\end{array}$ & Take out & - & $\checkmark$ & - \\
\hline 58. & $\begin{array}{l}\text { He made a list here one day, ticked off over the headings } \\
\text { A.B.C. (P.289) }\end{array}$ & Tick off & - & - & $\checkmark$ \\
\hline 59. & $\begin{array}{l}\text { The population of Great Britain turned itself into an } \\
\text { army of amateur sleuths.(P.143) }\end{array}$ & Turn into & - & $\checkmark$ & - \\
\hline 60. & $\begin{array}{l}\text { I turned this over in my mind without quite seeing the } \\
\text { point. (P.11) }\end{array}$ & Turn over & - & $\checkmark$ & - \\
\hline 61. & $\begin{array}{l}\text { You were at that time turning over in your mind various } \\
\text { plans for the murder of your brother.(P.290) }\end{array}$ & Turn over & - & - & $\checkmark$ \\
\hline 62. & $\begin{array}{l}\text { "I repeat then that, turning over various schemes in your } \\
\text { mind.(P.291) }\end{array}$ & Turn over & - & - & $\sqrt{ }$ \\
\hline 63. & I turned my attention to the postmark. (P.12) & Turn to & - & $\checkmark$ & - \\
\hline 64. & $\begin{array}{l}\text { "Well," I said presently, smiling, "has this super crime } \\
\text { turned up yet?"(P.11) }\end{array}$ & Turn up & $\sqrt{ }$ & - & - \\
\hline 65. & Without a word he walked into his bedroom. (P.8) & Walk into & - & - & $\checkmark$ \\
\hline \multirow{2}{*}{\multicolumn{2}{|c|}{ Total }} & \multirow[t]{2}{*}{65} & \multirow[t]{2}{*}{14} & 10 & 41 \\
\hline & & & & 51 & \\
\hline
\end{tabular}




\section{2 Results and Discussions}

4.2.1 The Syntax of Phrasal Verbs in 'The ABC Murders' (1936)

Table(4.2)The Syntactic Types of Phrasal Verbs in 'The ABC Murders' (1936)

\begin{tabular}{|c|c|c|c|c|c|c|}
\hline \multirow[t]{3}{*}{ No. } & \multirow[t]{3}{*}{ PVs } & \multicolumn{3}{|c|}{ Syntactic Types of PVs } & \multirow[t]{3}{*}{ Occurrence } & \multirow[t]{3}{*}{$\%$} \\
\hline & & \multirow[t]{2}{*}{ Intransitive } & \multicolumn{2}{|l|}{ Transitive } & & \\
\hline & & & Separable & Inseparable & & \\
\hline 1. & Bring + particles & - & - & 1 & 1 & 1.29 \\
\hline 2. & Call +particles & - & - & 1 & 1 & 1.29 \\
\hline 3. & Carry +particles & - & - & 1 & 1 & 0.64 \\
\hline 4. & Come + particles & 1 & - & 2 & 3 & 10.96 \\
\hline 5. & Do +particles & 1 & - & - & $\mathbf{1}$ & 1.29 \\
\hline 6. & Doze +particles & 1 & - & - & $\mathbf{1}$ & 0.64 \\
\hline 7. & Fall +particles & 1 & - & - & 1 & 2.59 \\
\hline 8. & Find +particles & - & - & 3 & 3 & $\mathbf{3 . 2 3}$ \\
\hline 9. & Get + particles & 2 & - & 1 & 3 & 7.09 \\
\hline 10. & Go +particles & 3 & - & 2 & 5 & 10.96 \\
\hline 11. & Grow +particles & 1 & - & - & 1 & 0.64 \\
\hline 12. & Hand +particles & - & 1 & - & 1 & 1.29 \\
\hline 13. & Hold + particles & - & - & 1 & 1 & 0.64 \\
\hline 14. & Keep+ particles & - & $\mathbf{1}$ & - & 1 & 0.64 \\
\hline 15. & Look + particles & $\mathbf{1}$ & - & 14 & 15 & 17.43 \\
\hline 16. & Pass + particles & - & - & 3 & 3 & 2.59 \\
\hline 17. & Pick + particles & - & - & 5 & 5 & 3.23 \\
\hline 18. & Put + particles & - & 1 & - & - & 4.52 \\
\hline 19. & Score + particles & - & - & 1 & $\mathbf{1}$ & 0.64 \\
\hline 20. & See + particles & - & - & 1 & 1 & 0.64 \\
\hline 21. & Send + particles & - & - & $\mathbf{1}$ & $\mathbf{1}$ & 1.29 \\
\hline 22. & Set + particles & - & $\mathbf{1}$ & - & $\mathbf{1}$ & 0.64 \\
\hline 23. & Slip + particles & - & 1 & - & 1 & 0.64 \\
\hline 24. & Spring + particles & 1 & - & - & 1 & 0.64 \\
\hline 25. & Take + particles & - & 2 & - & 2 & $\mathbf{3 . 2 3}$ \\
\hline 26. & Tick+ particles & - & - & 1 & 1 & 1.93 \\
\hline 27. & Turn+ particles & 1 & 3 & 2 & 6 & \\
\hline \multirow[t]{3}{*}{28.} & Walk+ particles & - & - & 1 & $\mathbf{1}$ & 0.64 \\
\hline & & $14(25.81 \%)$ & $10(20 \%)$ & $41(80 \%)$ & \multirow[t]{2}{*}{65} & \multirow[t]{2}{*}{$100 \%$} \\
\hline & & & \multicolumn{2}{|l|}{$51(83.33 \%)$} & & \\
\hline
\end{tabular}

According to the above statistical table, it is clear that the most common syntactic PV in 'The ABC Murders'(1936) is 'look + particles' which constitutes (15) from (65) which reads(23.07\%). PVs 'go/pick/take+ particles' have the same frequency with (5) for each one from the total (65) with a rate of (7.58\%). The PVs (come/find/get/ + particles) reads (3) with a rate of $(4.61 \%)$.The PVs (take + particles) reads (2) with a rate of $(3.07 \%)$ While the lowest using of PVs in these selected chapters of the novel mentioned above represented by 'bring/call/carry / do/doze /fall/ grow /hand/ hold / 
keep / score /see / send/set/slip/spring /walk + particles'. Each one of the lowest syntactic types of PVs in these chapters reads (1) only from the total (65) with a percentage of (1.53\%).

Generally ,the most common syntactic types of PVs in 'The ABC Murders' under analysis is 'Transitive' which shapes (51)from the total (65) and constitutes $(78.46 \%)$. These transitives are also divided into two subtypes : Inseparable PVs which read(41) from the total (51) with a percentage (80.39\%) and Separables which form(10) with a percentage (19.61\% ).While the second and lowest syntactic type of PVs that this table reveals is 'Intransitive' which reads (14)occurrences from the total (51) with a rate of $(21.54 \%)$.

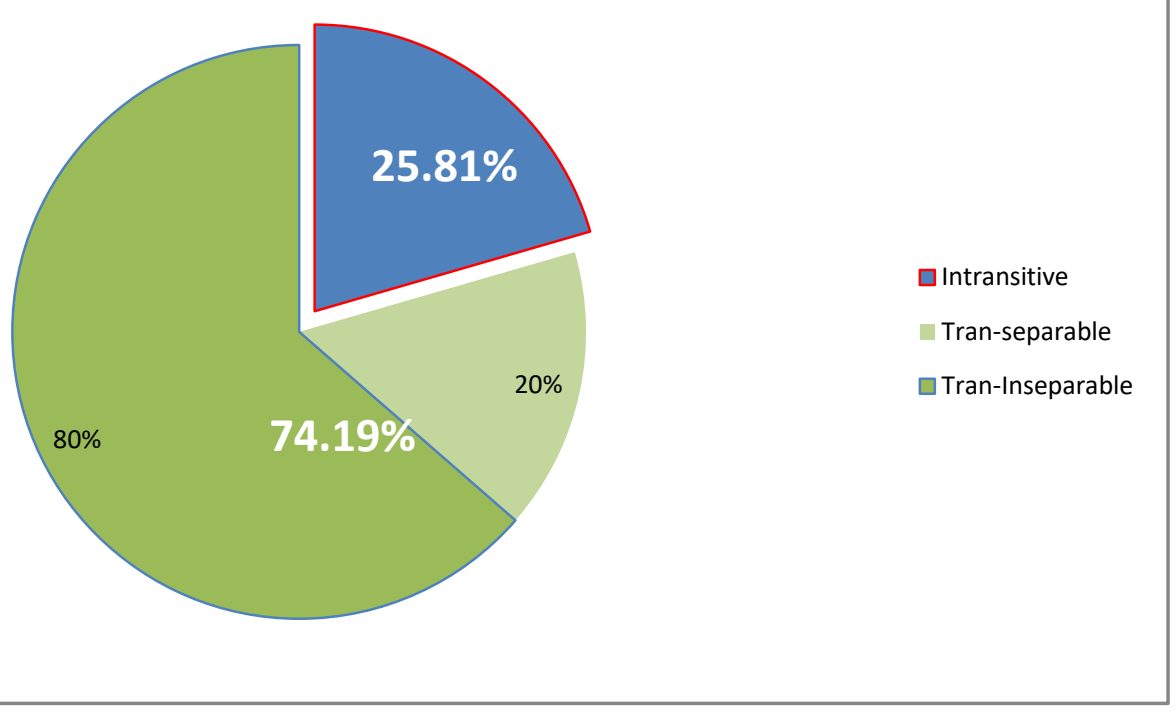

Figure(4.1)The Percentage of the Syntactic Types of Phrasal Verbs in 'The ABC Murders'(1936)

\section{CONCLUSIONS}

Based on the findings of the study, the following conclusions can be drawn :

1- Phrasal verbs are very important which are defined as combinations that consist of a main verb and a particle. When the prepositions or the adverbs are added to the main verb to make PVs, the combinations are used to give a large number of different meanings .

2- It becomes noticeable from the results of the study that Phrasal Verbs are rarely used in the Christie's"The ABC Murders". The total number of Phrasal Verbs from the main verbs (793) in "The ABC Murders" is (65) which constitutes $(8,196 \%)$.

3- The most common syntactic type of Phrasal Verbs in the novel is 'Transitive' which forms
(51) from the total (65)with a percentage of $(78.46 \%)$. Actually, this indicates that the writer is widely used Transitivity in her literary works.

4- 'Transitivity'as it is widely employed in Agatha Christie's literary works helps the reader to explore the world view of her and the character's personality and to start building the sentences which communicate with different events . Moreover, Transitivity would facilitate the interpretation of language in action , in context and would portrayhow the clause and its parts are potential sources of information (this can help covertly promote expressive language in her novels).

5- When it comes to the least common syntactic type of Phrasal Verbs, the study shows that : 
5.1. 'Intransitive' in 'The $\mathrm{ABC}$ Murders' constitutes (14) ) occurrences with a percentage of $(21.54 \%)$. However ,it can be said that 'Intransitive' is less frequent than 'Transitive' .

5.2 .According to the syntactic subtypes of Phrasal Verbs, the analysis shows that the most dominant transitive is 'Inseparable' which constitutes (41) instances with a percentage of $(80.39 \%)$ in the novel. Whereas 'Separable' shapes (10)occurrences with a rate of $(19.61 \%)$. Actually, all IntransitivePhrasal verbs are Inseparable .

6- In general, it is clear from the analysis of the novel that the Transitive is the outstanding syntactic type of Phrasal Verbs (i.e. transitivity expressions). This also reflects the fact that Christie's style of writing would reflect 'Expressiveness'.

\section{REFERENCES}

Alexander ,L.G.(1990).Longman English Grammar Practice(1st ed) .UK: Longman Group UK Limited.

Barlow,M. and Burdine, S. (2006).American English Phrasal Verbs and collocations. Houston, USA: Athelstan Publications.

Cawthorne ,N.(2014) .Agatha Christie :Queen of Crime (1st ed.).UK: Constable\& Robinson Ltd.

Chen, J. (2007). On How to Solve the Problem of the Avoidance of Phrasal Verbs in the Chinese Context. International Education Journal,8(2), 348-353 .Retrieved from https://eric.ed.gov/?id=EJ834272

Christie, A.(1936).The ABC Murders(1st ed.).London, UK : Collins ,The Crime Club.

Coulthard, M. 1985. An Introduction to Discourse Analysis(2nded).New York : Longman Group Limited.

Crystal, D.(2008). A Dictionary of Linguistics and Phonetics (6thed.). Oxford : Blackwell Publishing Ltd.

(1995).Cambridge Encyclopedia of the English Language.

Cambridge : Cambridge

University Press.

Dixon, R. M. W. (1992). A New Approach to English Grammar, on Semantic Principles. Oxford: Clarendon Press.

Downing, A.\& Locke ,P.(2006).English Grammar: A University Course Second edition.(2nd ed.).USA: Routledge.

Eastwood, J.(2002).Oxford Guide to English Grammar(7th ed.). Oxford: Oxford University Press .

Fletcher ,B.(2005). Register and Phrasal Verbs . MED-Magazine(33) .Retrieved from

http:// www .macmillandictionaries. com / MEDMagazine /September 2005 /33 - Phrasal-Verbs Register.

Gale, S. L.(2016). A Study Guide for Agatha Christie's "The A.B.C. Murders," Retrieved from https://books.google.com

Gardner, D., \& Davies, M. (2007). Pointing out frequent phrasal verbs: A corpus based analysis .Cited in Ngoc Tu ,T. P. \& Thao ,T. Q.(2018)

Halliday, M.A.K. (1994). An introduction to functional grammar (2nded.). London: Edward Arnold.

Hart, C. ,W.(2017).The Ultimate Phrasal Verb English Book(3rd ed.).New York: Barron's Educational Series, Inc.

Kandilji,A. \& Al-Samarrai , I.(2009). Scientific Research: Quantitative and Qualitative. Amman „Jordon :Alyazori Publishing house

Kastan, D.S. (2006). The Oxford Encyclopedia of British Literature. 1. Oxford: Oxford University Press.

Kodirova, B. Z.(2020).Mystery and Suspense in The ABC Murders. International Journal on Integrated Education (2020).Vo.3 (1).

Kolln, M. ,and Funk, R. (2012). Understanding English Grammar. (9th ed.). Boston ,USA : Pearson Education, Inc. 
Leech ,G. (2006). A Glossary of English Grammar(1st ed ). UK: Edinburgh University Press. Lester ,M.(2009). English Grammar Drills. New York ,USA: The McGraw-Hill Companies, Inc. McArthur, T.(1992).The Oxford Companion to the English Language.Oxford, UK: Oxford University Press. McCarthy ,M.;O’Dell,F.(2004).English Phrasal Verbs in Use: Intermediate(1sted.). Cambridge, UK : Cambridge University Press.

.(2007).English Phrasal Verbs in Use: Advanced(1st ed.).Cambridge, UK : Cambridge University

Press.

Murphy, R. (2012). English Grammar in Use(4th ed.). Cambridge ,UK: Cambridge University Press.

Newson, M. (2006). Basic English Syntax with Exercises .Budapest, Hungary: Bölcsész Konzorcium.

Olson, A. (2013). Thesis "Constructions and Result: English Phrasal Verbs as Analysed in Construction

Grammar”. Trinity Western University Retrieved on 5/8/2019 https://www.twu.ca/sites/default/files/olson_a_l.pdf

Palmer ,F.R.(1987).The English Verb (2nd ed.)UK: Longman Group UK Limited.

Quirk, R.; Greenboun, S.; Leech, G. and Svartvich, J. (1972).A Grammar of Contemporary English (1st ed.) .UK : Longman Group Ltd

.(1985). A Comprehensive Grammar of English Language. London: Longman Group

Ltd.

Redman ,S. (1997).English Vocabulary in Use . Cambridge : Cambridge University Press.

Rudzka-Ostyn, B. (2003).Word Power: Phrasal Verbs and Compounds. Berlin, Germany: Mouton de Gruyter.

Seidl ,J.; and McMordie, W.(1988).English Idioms(5th ed). UK, Oxford : Oxford University Press.

Sroka, K. A. (1972). The syntax of English Phrasal Verbs. The Hague: Mouton.

Swan , M . (1995).Practical English Usage . (2nd ed .) Oxford : Oxford University Press.

Tu , N. T. P. \& Thao ,T. Q.(2018). The Use of Phrasal Verbs in English Language Research Proposals by Vietnamese M.A. Students . VNU Journal of Foreign Studies, Vol.35, No.4 (2019).

Vurmay,M.A.(2017) .Detection or Endless Deferral / Absence in Detective Fiction: Agatha Christie's And Then There Were None. DTCF Dergisi Journal. Vo.57(2) Retrieved on 27, October, 2019

Zhang, P. (2001) .A Discourse Stylistic Approach to the Critics of Christie's Works, Comparative Literature: East \& West, 3(1), 134-154.Retrivied from https://doi.org/10.1080/25723618.2001.12015284 